\title{
Handbook of Florida Water Regulation: Florida Right-to-Farm Act ${ }^{1}$
}

\author{
Michael T. Olexa, Luke D'Isernia, Laura Minton, Dulcy Miller, and Sarah Corbett ${ }^{2}$
}

\section{Preface}

This handbook is designed to provide an accurate, current, and authoritative summary of the principle Federal and Florida laws that directly or indirectly relate to agriculture. This handbook should provide a basic overview of the many rights and responsibilities that farmers and farmland owners have under both Federal and Florida laws as well as the appropriate contact information to obtain more detailed information. However, the reader should be aware that because the laws, administrative rulings, and court decisions on which this handbook is based are subject to constant revision, portions of this publication could become outdated at anytime. Several details of cited laws are also left out due to space limitations.

This handbook is distributed with the understanding that the authors are not engaged in rendering legal or other professional advice, and the information contained herein should not be regarded as a substitute for professional advice. This handbook is not all inclusive in providing information to achieve compliance with the Federal and Florida laws and regulations governing water protection. For these reasons, the use of these materials by any person constitutes an agreement to hold harmless the authors, the Florida Cooperative Extension Service, the Institute of Food and Agricultural Sciences, and the University of Florida for any liability claims, damages, or expenses that may be incurred by any person as a result of reference to or reliance on the information contained in this handbook.

\section{Overview}

The Florida state government recognizes that agriculture is a major contributor to the Florida economy, that lands under cultivation constitute irreplaceable resources and preserve the landscape and environmental resources of Florida. In recognition of these beneficial attributes and the fact that farm operations (farming) in urbanizing areas is potentially subject to nuisance lawsuits, which encourages and forces the premature removal of farmland from agricultural use, the Florida Legislature passed the Florida Right-to-Farm Act

1. This is EDIS document FE599, a publication of the Food and Resource Economics Department, Florida Cooperative Extension Service, Institute of Food and Agricultural Sciences, University of Florida, Gainesville, FL. Published December 2005. Please visit the EDIS website at http://edis.ifas.ufl.edu.

2. Michael T. Olexa, Professor, Food and Resource Economics Department, Florida Cooperative Extension Service, Institute of Food and Agricultural Sciences, University of Florida, Gainesville, FL; Director, Agricultural Law Center, University of Florida, Gainesville, FL; and Chair, Agricultural Law Committee of The Florida Bar. Luke D'Isernia, former student (graduated cum laude in 2005), Levin College of Law, University of Florida, Gainesville, FL. Laura Minton, Attorney, Dean, Mead, Egerton, Bloodworth, Capouano, and Bozarth, Orlando, FL. Dulcy Miller, attorney, Foley and Lardner, LLP, Orlando, FL. Sarah Corbett, Attorney, Florida Second District Court of Appeal, Lakeland, FL. 
(FRTFA) to protect reasonable farm operations from nuisance lawsuits.

\section{How Does the FRTFA Restrict Nuisance Lawsuits?}

The FRTFA [Florida Statutes, Section 823.14] restricts nuisance suits against farmers by providing that farm operations which have been in operation for a year or more since they were started, and which were not nuisances when they were established, will not constitute a public or private nuisance if the farm operations conform to generally accepted agricultural and management practices.

The provisions of the FRTFA are not affected by change of ownership, changes in the farm product(s) being produced, changes in the conditions in or around the locality of the farm, or those changes brought by compliance with the Best Management Practices (BMPs) adopted by local, state, or federal agencies.

In addition, FRTFA provides that local governments may not adopt any rules or ordinances which restrict or limit a bona fide farming activity that is conducted on agricultural lands in accordance with implemented BMPs.

Expansion of farm operations within the original boundaries of the farm, and expansion of the farms land boundaries do not strip the farm operation of its previous date of operation.

\section{What Does the FRTFA Require and Prohibit?}

The FRTFA requires that farm operations be reasonable, by conforming to generally accepted agricultural and management practices, in order to be protected from nuisance lawsuits. However, the FRTFA does not extend protection to farming operations in which the following are found:

- Untreated or improperly treated human waste, garbage, dead animals, dangerous waste materials, or gases which are hazardous to human or animal life.
- Improperly built or maintained septic tanks, indoor or outdoor toilets, or showers.

- Unsanitary conditions in places where animals are slaughtered, which may give rise to diseases that are harmful to humans or animals.

- Keeping of diseased animals which are dangerous to human health, unless they are kept in accordance with a state or federal disease control program.

FRTFA also prohibits an existing farm operation from changing to a more excessive farm operation with regard to noise, odor, dust, or fumes where the farm operation is adjacent to an established residence or a business.

Furthermore, FRTFA does not give the farmer a license to violate the principles of negligence or nuisance law, or to pollute the environment.

Contaminating water wells or misapplying pesticides (pesticide drift onto neighboring properties) will still open the farmer up to a potential lawsuit.

Non-point source pollution (runoff) from farms, especially farms in which the above four conditions are found, can cause bacteria, nutrients such as phosphorus, and other substances to enter and contaminate surface waters. Groundwater can also be contaminated by seepage from farms. This can lead to violations, liability, and penalties under several of the acts and programs discussed in this handbook, unless the appropriate measures are taken to reduce the amount of contaminates that enter the water, such as storing and managing facility wastewater and runoff with an appropriate waste management system.

For more information regarding farmers rights under the Florida Right-to-Farm Act and other acts, please contact the Florida Department of Agriculture and Consumer Services.

\section{Source}

Chapter 832, Florida Statutues, Section 832.14

\section{Acknowledgments}

The authors are indebted to the personnel of both state and federal agencies who provided their time 
and advice in the preparation of this handbook. The authors are especially indebted to Richard Budell of the Office of Agricultural Water Policy of the Florida Department of Agriculture and Consumer Services for providing funds for the development of this publication. 